ljtihad, Jurnal Wacana Hukum Islam dan Kemanusiaan

Vol. 18, No. 1 (2018), pp. 99-118 doi : 10.18326/ijtihad.v18i1.99-118

\title{
Dialektika nalar idealitas dan nalar realitas: aplikasi konsep 'umūm al-balwō dalam dinamika hukum Islam
}

\author{
Firman Muhammad Arif \\ Institut Agama Islam Negeri (LAIN) Palopo \\ E-mail: firmanari@iainpalopo.ac.id \\ DOI: 10.18326/ijtihad.v18i1.99-118
}

The application of law is not always oriented towards things that are ideal. There are certain other considerations or exceptions to the application of rules because they are beyond knowledge and no control. The general concept of umüm al-balwa to fulfill interests including eliminating difficulties. By using qualitative descriptive analysis and considerations that are difficult to avoid or difficult to avoid become special considerations that result in dispensation. Cases that afflict human life are linked to other matters in various fields with the uniformity of considerations and the impact of giving relief which ends in making it easy but not easy.

Penerapan hukum tidak selamanya berorientasi mengarah pada hal-hal yang ideal. Ada berbagai pertimbangan tertentu lainnya atau pengecualian dari penerapan aturan karena diluar pengetahuan dan ketiadaan kendali. Konsep umüm al-balwä bertujuan memenuhi kepentingan termasuk menghilangkan kesulitan. Dengan menggunakan analisis deskriptif kualitatif dan pertimbangan susah untuk dihindarkan atau susah menghindarkan diri menjadi pertimbangan khusus yang mengakibatkan terjadinya dispensasi (rukhs\}ah). Perkara yang menimpa kehidupan manusia dipertautkan dengan perkara lainnya dalam berbagai bidang dengan adanya keseragaman pertimbangan dan berdampak diberikannya keringanan yang berujung pada memudahkan namun bukan memudah-mudahkan.

Keywords: substance of umum al-balwa; ideality; reality; social dynamic

\section{Pendahuluan}

Syari'at Islam dengan berbagai ketentuannya telah ditetapkan Allah dan hasil pemahaman atas dasar ketentuan tersebut dijadikan pegangan oleh umat manusia dalam hubungannya 
dengan Tuhannya, dengan sesamanya juga dengan lingkungan sekitarnya (Syaltut, 1966: 12). Didalamnya terdapat berbagai aturan yang diperuntukkan bagi manusia dalam ranah kehidupan ritual atau sosial. Eksistensi syari'at sebagai ketetapan Allah dan Rasul-Nya berisi ketentuan-ketentuan hukum dasar yang bersifat global, kekal, dan universal yang diberlakukan bagi semua hamba-Nya baik dalam bidang akidah, ibadah, dan muamalah. Segala sesuatu yang berkaitan dengannya merupakan hak prerogratif Allah swt (Ismatullah, 2011: 35-36).

Kesempurnaan Islam ditegaskan Allah swt untuk diyakini pemeluknya sebagai sebuah keyakinan dan agama yang sempurna. Ketegasan tersebut ditunjukkan dalam pesan al-An'am: 38 bahwa tiada sesuatu apapun yang dialpakan di dalam al-Kitab. Ayat tersebut dijadikan sebagai landasan naqli sebagaimana yang disampaikan Imam Syafi'i bahwa apapun yang dinyatakan manusia dari sebuah kebenaran adalah representasi pola hidup Rasulullah saw. dan segala sesuatu yang disampaikan Rasulullah saw. merupakan penjelasan yang terdapat dalam Alquran (Ibrahim, 2002: 3).

Ulama tafsir menafsirkan kata "al-Kitab" di surah al-An'am sebagai Alquran dengan pokok-pokok agama, norma-norma hukum, hikmah-hikmah, dan tuntunan untuk kebahagiaan manusia di dunia dan akhirat, serta kebahagiaan makhluk secara umum (Majma', 2017: 192). Pernyataan tersebut menunjukkan bahwa keberlakuan hukum Islam tidak hanya berdimensi masa lalu, tapi juga berdimensi masa kini dan bahkan berdimensi masa depan.

Islam sebagai agama rahmat kepada semesta alam dengan hukum-hukum yang terdapat didalamnya, ditetapkan dengan tujuan untuk memenuhi kepentingan manusia dan menjauhkan hal-hal buruk termasuk menghilangkan kesulitan dan kesusahan. Universalitas dan sifat dinamis dari awal risalah Islam, telah banyak menyinggung masalah yang berkaitan kehidupan kemasyarakatan dengan pesan-pesan yang sarat dengan dimensi ilahi, termasuk sengketa, perang, perdamaian, bahkan sikap terhadap tawanan perang dengan begitu paripurna (Ashri, 2013: 3).

Hukum adalah produk yang lahir dari dinamika kehidupan manusia dan menunjukkan dimana ada masyarakat di sana ada hukum. Penerapan hukum dengan pertimbangan sosiologis bukan berarti penilaian terhadap hukum tetapi perhatiannya dengan memberikan penjelasan terhadap objek yang dipelajarinya. Pendekatan hukum dari segi objektifitasnya bertujuan untuk memberikan penjelasan terhadap fenomena hukum yang nyata (Ali, 2012: 9). 
Hukum dijadikan kontrol sosial dan proses yang bersifat mendidik, mengajak, atau bahkan memaksa warga masyarakat mematuhi sistem kaidah dan nilai yang berlaku (Ali, 2012: 22).

Perkembangan masyarakat dari purbakala yang primitif sampai sekarang telah diliputi modernitas dalam berbagai sistem yang selanjutnya mengubah manusia menjadi maju dan modern sehingga sektor hukum harus selalu mengiringi dan mengikuti perkembangan masyarakat. Artinya, dalam masyarakat yang maju dan modern maka hukum harus maju dan modern pula (Mustofa, 2009: 5). Perwujudan hukum sebagai sosial kontrol bisa berupa pemidanaan, terapi, maupun konsiliasi. Pada terapi atau konsiliasi sifatnya "remedial" artinya mengembalikan situasi (interaksi sosial) pada keadaan semula. Konsiliasi menunjukkan keterbukaan yang standarnya adalah normalitas, keserasian, dan kesepadanan yang biasa disebut dengan keharmonisan (Ali, 2012: 23).

Marcus Tullius Cicero (Romawi) dalam De Legibus menyatakan hukum adalah akal tertinggi yang ditanamkan oleh alam dari manusia untuk menetapkan apa yang boleh dan apa yang dilarang. Hukum Islam dengan kumpulan konkret didalamnya dari masa Nabi dinilai sebagai asas-asas umum yang dapat diijtihadkan ke berbagai aspek kehidupan yang dinamis (Mustofa, 2009: 1-2). Karakteristik hukum Islam bersifat teistis (rabbaniyah), etis (akblaqiyah) yang memelihara idealisme moral dengan batasan pertimbangan akal, humanistis (insaniyah), keteraturan (tanasuq), komprehensif (syumul), dan waqi'iyah (al-Qaradhawi, 1981: 94).

Sifat realistis mempertimbangkan kondisi darurat dan kondisi menyulitkan yang kadang terjadi dalam kehidupan manusia, baik bersifat individual maupun kelompok. Bahkan kebutuhan sekunder kadang-kadang dapat dikategorikan sebagai kebutuhan darurat untuk memudahkan umat dan mencegah bahaya yang ditimbulkannya (Sultan, 2014:18). Dengan demikian kerangka rukhsah (keringanan) dibenarkan dalam hukum syara' dan kesulitan bisa mendatangkan kemudahan adalah qaidah fiqhiyyah yang menjadi dasar penting untuk menyingkap maksud syari'ah (Abbas, 2000: 77).

Fikih diasumsikan sebagai formula yang dipahami dari syariat, sebab syariat tidak bisa jalan dengan baik tanpa dipahami melalui fikih atau pemahaman yang memadai dan diformulasikan secara baku. Realitas ontologis syariat selanjutnya melahirkan aspek epistemologi hukum Islam atau fikih yang mempresentasikan hasil interaksi penalaran ulama dengan latar belakang aspek sosial yang berbeda dalam menetapkan suatu hukum (Idrus, 2012: 5). Produk dari 
tasyri' wad'i atau penetapan hukum yang dilakukan kalangan mujtahid menunjukkan adanya intervensi ra'yu (rasio) yang berkualitas ijtihadi sebagai respons bagi problematika hukum umum yang berkembang ketika diktum-diktum fikih itu ditulis (Abdain, 2013).

Beranjak dari beberapa karakteristik tersebut mengiring pada persepsi lanjutan bahwa hukum Islam jika diposisikan pada hukum positif telah nampak fleksibilitasnya dan pemahaman tersebut semakin mengidentikkan Islam sebagai agama yang tidak kaku (Sultan, 2014: 19). Kepentingan manusia harus tetap diikutkan untuk melepaskan dominasi sistem tirani dengan dalih menjalankan otoritas Allah dalam bidang hukum yang diperani oleh fuqaha atau para penguasa sehingga dibutuhkan kompensasi saat didapatkan kesulitan (Fanani, 2009: 222).

Keringanan diistilahkan sebagai kompensasi yang standar patokannya kewajiban, dimana inisiatif untuk memprosesnya ada pada pihak yang dirugikan. Pihak yang dirugikan meminta ganti rugi dan pihak lawan melakukan wanprestasi (Ali, 2012:23). Keringanan yang diberikan tidak lain sebagai upaya mengakomodir dan mengantisipasi persoalan yang dihadapi sehingga terkesan bahwa hukum Islam tidak kaku, stagnan, tetapi fleksibel dan punya daya lentur yang bersikap moderat serta diartikan ketetapan-ketetapan syara' yang mempresentasikan spirit Islam bagi hamba-hamba-Nya (al-Syatibi, 2003: 215).

Eksistensi qä̊rdah fiqhiyyah yang natural berdasarkan peristiwa yang terjadi dan memiliki sifat qat'i (pasti) karena dalil-dalil primer menjadi tumpuannya sehingga landasannya terlihat ideal dan sempurna. Menurut al-Syatibi, dalil-dalil tentang dispensasi (menghilangkan kesulitan) sudah mencapai tingkat qat'i (Syatibi: 231) yang mengintegrasikan hukum-hukum yang berpihak kepada kemudahan sebagai tujuan dasar dari "pemilik syari'ah yang bijaksana" dalam memberlakukan syari'ah Islam (al-Nadwi, 1991: 265).

Apapun yang terdapat dalam syariat tentang amr (perintah, tuntutan), naby (larangan), dan mubah (sesuatu yang boleh dikerjakan) haruslah sejalan dengan nilai-nilai ketuhanan dan terintegrasi dengan nilai-nilai kemanusiaan (Syatibi: 228). Optimalisasi kemampuan dalam merumuskan istinbat hukum tidak dapat dipisahkan dari rasionalitas sebagai upaya perenungan terhadap masalah-masalah tertentu berdasarkan Alquran dan hadis atau prinsipprinsip umum syari'at (Minhajuddin, 2010: 131). Alquran dan Sunnah sebagai wahyu matlu dan ghairu al-mutlu dalam realitasnya tidak dapat mengabaikan peran akal karena Alquran 
tidak semata-mata memberi perintah tetapi juga memotivasi agar berpikir (Ismatullah: 123).

Alquran dan Sunnah sebagai pedoman pokok dalam beberapa hal masih memerlukan penjelasan untuk memahaminya disebabkan pengertiannya yang bersifat umum sehingga susah untuk dimengerti tanpa ditakhsiskan. Maka disinilah peran metode penggalian hukum yang terkandung dalam Alquran dan Sunnah. Keperluan akan pengkajian dan interpretasi, baik secara teksual maupun tekstual menunjukkan bahwa Islam sebagai ajaran sempurna yang selaras dan sesuai dengan keadaan, zaman dan tempat (al-Qaradhawi, 1997: 11-15).

Piranti ijtihad digunakan untuk memperoleh sangkaan yang berat atau hukum yang bersifat z\}anni dalam meng-istinbat-kan suatu hukum untuk diamalkan (Djalil, 2010: 178) telah mengalami progresifitas dari masa ke masa yang berangkat dari upaya cendekiawan muslim pasca abad klasik dalam meracik metodologi instinbat sehingga dianggap sangat penting bagi generasi selanjutnya dan patut untuk diapresiasi. Upaya mengeksplorasi hukum syari'ah tidak terlepas dari segi kebahasaan karena hampir delapan puluh persen penggalian hukum syariah menyangkut lafaz yang menunjukkan hukum harus jelas dan tegas supaya tidak membingungkan para pelaku hukum. Meskipun dalam realitasnya ada petunjuk lafaz dalam nas syara' beraneka ragam sehingga ijtihad diperlukan untuk menetapkan bahwa pemahaman teks/lafaz tersebut didasarkan pada kaidah yang harus dipegangi yaitu petunjuk kebahasaan dan petunjuk dari Nabi (Kamma, 2012: 1-7).

Namun perlu digarisbawahi bahwa formula tersebut bukanlah konstitusi baku yang tidak mengalami perkembangan apalagi stagnan. Sejak dikenalnya usul fikih maka sejak itu diperkenalkan pengembangan hukum yang sejalan dinamika masyarakat dan mengalami progresifitas dengan pola pengembangan dan pembaruan. Ilmu usul fikih menjadi metodologi terpenting yang ditemukan oleh dunia pemikiran Islam dan tidak dimiliki oleh umat lain (Garisyah, 1989: 56). Tidak sebatas metodologi baku bagi hukum Islam tapi juga berlaku bagi seluruh pemikiran intelektual Islam karena tidak dibatasi pada penemuan peraturan hukum konkret tapi diarahkan pula kepada penggalian asas-asas dengan mempertimbangkan pendekatan pertingkatan norma sehingga lebih mudah merespon berbagai perkembangan masyarakat dari sudut hukum syariah (Idrus, 2013: 190).

Ilmu usul fikih yang bersamaan munculnya dengan ilmu fikih meskipun dalam penyusunannya ilmu fikih dilakukan lebih dahulu dari usul fikih. Sebenarnya ilmu fikih 
harus didahului oleh usul fikih karena ketentuan atau kaidah harus diikuti mujtahid pada saat menghasilkan fikihnya namun dalam perumusannya usul fikih datang belakangan (Syarifuddin, 2009: 42). Hal tersebut bisa dilihat dalam perkembangan hukum Islam dari aspek sosio historisnya dengan tiga paradigma penalaran filosofis, yaitu penalaran literalistik bercorak usul fikih klasik, paradigma penalaran usul fikih berbasis maqāsid asy-syari’ah dan paradigma penalaran ilmiah (Idrus, 2012: 173). Konsep-konsep usul fikih menghendaki agar hukum tidak terisolir dari aspirasi masyarakat dan begitupun sebaliknya masyarakat tidak boleh berjalan tanpa supremasi hukum (Fanani, 2009: 221).

Nama-nama besar intelektual Islam semacam Imam Abu Hanifah al-Nu'man bin Tsabit (w. $150 \mathrm{H}$ ), dikenal sebagai ahli fikih yang memiliki kecenderungan menggunakan rasio cukup tinggi dan ijtihadnya didominasi penggunaan akal dalam bentuk rumusan qiyās dan istiḅsān sebagai standar dalam metodologi istinbath hukum (Ismatullah, 2011: 295). Pengembangan metodologi Imam Abu Hanifah yang begitu luas dipopulerkan sebagai mazhab rasionalis (ahli ra'yl). Pada masanya sempat ditawarkan posisi qạdi (hakim) di akhir Dinasti Umayyah saat gubernurnya Ibnu Hubairah. Demikian juga saat awal Dinasti Abbasiyyah masa Abu Ja'far namun ditolaknya hingga beliau dipenjara dan meninggal tahun $150 \mathrm{H}$ (Mahmasani, 1952: 29-30).

Selanjutnya Imam Malik dengan formula mas lahah mursalah-nya ketika tidak mendapatkan ketetapan hukum dari nash, baik dari Alquran, hadis, amalan ahli Madinah dan perkataan sahabat (Mahmasani, 1952: 38). Maslahah mursalah sebagai ciri khas pemikirannya yang diduga kuat dipengaruhi pemikiran tokoh sahabat seperti Umar bin Khattab yang kemudian mendapat pengakuan dan legitimasi dari semua mazhab sesudahnya meskipun dengan sebutan yang berbeda (Ismatullah, 2011: 301). Pemakaian maslahah mursalah harus memenuhi syarat bahwa masalah yang ingin ditetapkan masuk dalam kategori muamalah yang logis, maslahatnya selaras dengan spirit syariat, dan maslahatnya dikategorikan dalam hal-hal yang darurat dan kebutuhan saja (Mahmasani, 1952: 130).

Adapun Imam Syafi'i sebagai peletak embrio ilmu usul fikih dengan hierarkis sumber hukum Islam menjadi empat: Alquran, hadis, ijma, dan qiyas (Ismail, 1981: 25). Kehadirannya di tengah pergulatan abli hadis dan abli ra'yi dipresentasikan sebagai upaya rekonsiliasi. Pada diri Syafi'i terkumpul pemikiran hampir semua ulama terkemuka pada zamannya yang pernah 
menjadi guru Syafi'i atau berbagai hal pernah mendiskusikan beragam persoalan dengannya. Tercatat guru-guru yang sangat pakar di bidangnya sekitar 19 orang. Lima diantaranya dari kota Mekkah, 6 orang berasal dari Madinah, 4 orang dari Yaman dan 4 orang dari Irak (Ismatullah, 2011: 307).

Lain halnya dengan Ahmad bin Hanbal (w. $241 \mathrm{H}$ ) dikenal sebagai tokoh yang jujur karena pikiran-pikirannya dipandang orisinal dan ikut memberikan warna bagi iklim keilmuan dan keislaman. Penalaran hukum Imam Ahmad lebih komprehensif yang berakar pada realitas sosial budaya yang berkembang pada masanya dan yang muncul pada imam mazhab sebelumnya. Ketekunannya dalam mengambil pelajaran dari ilmu dan tajdid imam mazhab sebelumnya sehingga ia dapat melampaui mereka (Idrus, 2013: 18). Pertarungan gagasannya dengan penguasa bermazhab Mu'tazilah dicatat sebagai simbol kemandirian keilmuan yang berdampak pada popularitasnya di abad ketiga hijriah. Produktifitas yang ditandai dengan karya-karya ilmiah yang dihasilkan menunjukkan kondisi yang mendukung bagi perkembangan aktifitas keilmuan dan kebebasan ilmiah (Ismatullah, 2011: 286).

Dalam fikih klasik khususnya yang berkenaan dengan ibadah mạ̣dah, persoalan-persoalan yang susah dihindari bisa ditolerir atau diberikan dispensasi. Contohnya saat Abu Qatadah yang tidak menganggap bekas air minum dari binatang semacam kucing dengan dalih bahwa hewan seperti kucing adalah hewan yang selalu berada dalam lingkungan manusia sehingga sulit untuk dihindari kendati kucing adalah hewan yang kerap memakan binatang yang dianggap najis dan menjijikkan seperti tikus (Kawari, 2010: 25).

Begitupun dengan fenomena salatnya penjual ikan yang sisik-sisik ikan yang tetap menempel di pakaian yang dikenakannya dan dipakai dalam melaksanakan salat dapat dijadikan sebagai alasan rukhşah atau diberikan dispensasi hukum karena kesulitan untuk mengelak dari perkara tersebut. Begitupun dengan kotoran tikus yang masuk dalam wadah tempat air yang dipakai untuk bersuci tentunya sulit untuk dihindari dan sudah sewajarnya diberikan dispensasi dan keringanan (al-Malibari: 11). Situasi yang seperti ini diistilahkan dalam fikih klasik dengan istilah umūm al-balwā.

Konsep umūm al-balwā didasarkan dari riwayat Abu Qatadah menunjukkan bahwa konsep tersebut mengcounter persoalan ibadah dengan dalih sulit dihindari sehingga perlu diberikan dispensasi. Rukhsah atau dispensasi hukum dalam agama tidak hanya sebatas bidang ibadah 
tapi bisa diikutsertakan dalam bidang muamalah, privat (ahwäl al-syakhsiyyah), dauliyyah, abkām jinäiyyah (hukum publik), abkām dustüriyyah, abkēm māliyyah dan iqtișādiyyah. Keumuman pemberlakuan dispensasi diakomodir dengan landasan teks Alquran dan hadis yang mentolerir beberapa persoalan dalam dinamika kehidupan yang biasanya sulit untuk dihindari.

\section{Etimologi dan terminologi 'umūm al balwā}

Tradisi masa jahiliyah era pra Islam seperti tradisi diyat dalam kasus pembunuhan, kafáah dalam pernikahan, kebiasaan pinjam meminjam dalam muamalah, membungkus ka'bah dalam ibadah, serta tradisi-tradisi lainnya yang dianggap terpuji ditetapkan dalam syari'at (al-Buti, 2010: 93). Ritualitas bangsa Arab sebelum adanya Islam tidak diingkari bahkan dilestarikan. Perilaku-perilaku sosial masyarakat Arab mendapat perhatian hukum Islam dengan mengubah tradisi jahiliyah karena bertentangan dengan ajaran Islam. Keberhasilan hukum Islam mengubah masyarakat Arab tidak hanya berakar pada realitas sosial tetapi karena faktor transedensi yang dituntun oleh wahyu dengan adanya tahapan atau pertimbangan kondisi sosial (Idrus, 2012: 17).

Konsep umüm al-balwā selalu memposisikan maslahat di garda terdepan terhadap tradisi dan kondisi masyarakat. Konsep umūm al-balwā tidak bisa dilepaskan keterkaitannya dengan konsep maslahat, 'urf (adat istiadat), maqāsid asy-syari’ah (hikmah hukum Islam) yang juga punya korelasi dengan qawä'id fiqhiyyah (kaidah-kaidah produk hukum Islam). Pemberlakuan umūm al-balwā dalam berbagai aspek menuntut adanya formula dan rumusan yang bisa disepakati sehingga tidak menjadi wilayah perselisihan. Selanjutnya bisa dijadikan tumpuan menyikapi beragam isu dan mengakomodir kebutuhan masyarakat terkhusus penganutnya.

Konsep umūm al-balwā dirangkaikan dengan dua kata yaitu umūm dan al-balwā. Kata

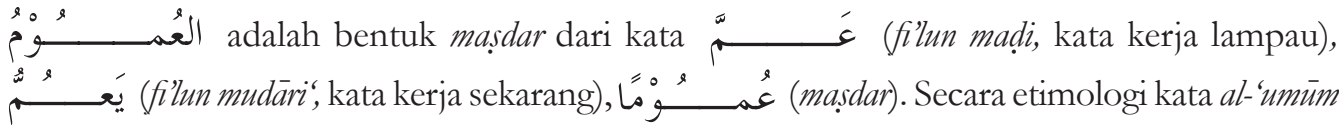
berarti al-tuul (sesuatu yang panjang), al-kasirah (sesuatu yang banyak), al-'ulummu (sesuatu yang tinggi), asy-syumul (sesuatu yang mencakup) (Manzur: 321). Dalam ungkapan yang lainnya seperti شمل الجماعة yang berarti mencakup perkara kolektif (al Bustani, 1992: 529).

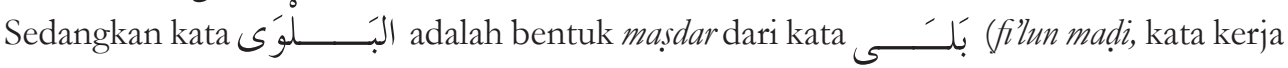




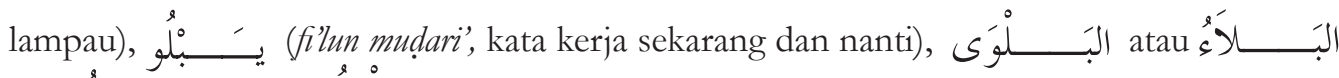

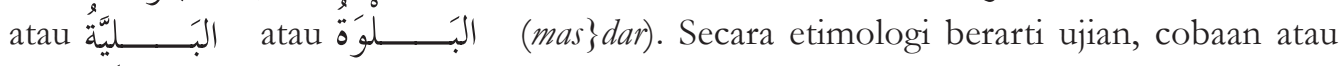
bencana (Manzur: 90). Secara terminologi, pakar usul fikih maupun pakar fikih cenderung mengistilahkan 'umūm al-balwā dengan ungkapan fima'ammat baliyyatubu atau ma ta'ummu bihi al-balwā (al-Zarqa, 2012: 161). Definisi terminologi ulama tidak jauh berbeda dengan apa yang termaktub dalam definisi etimologinya. Ekspektasi dari substansi terminologinya adalah kejadian yang bertumpu pada beban dan dilaksanakan mukallaf namun sulit terhindarkan.

Dalam aspek terminologi dari ulama salaf (klasik) masih jarang ditemukan definisi 'umūm al-balwā secara terpisah. Mayoritas didefinisikan saat membahas keterkaitan umūm al-balwā dengan khabar wäh\}id, seperti definisi dalam kitabnya usul al-fiqhi (al Khadari, 1969: 234) bahwa khabar wāhid yang didalamnya ada unsur 'umüm al-balwa dibutuhkan oleh mukallaf dengan kebutuhan yang benar-benar dibutuhkan karena peristiwa tersebut sering terjadi.

Ulama salaf mendefinisikan 'umūm al-balwā secara ringkas dan meliputi ruang dan makna beban pentaklifan yang berlebihan. Seperti definisi al-Tufi ketika menyandingkannya dengan khabar wāhid dengan ungkapan lain (al-Turki, 1998: 233) bahwa Khabar wähid yang didalamnya terdapat'umūm al-balwā adalah khabar wähid yang banyak memberikan beban pentaklifan.

Sedangkan al-San'ani dalam kitabnya Ijabatu al-Säil Syarhu Bagiyyati al-Amil mendefinisikan 'umüm al-balwā dengan ungkapan menyeluruhnya beban pentaklifan kepada seluruh mukallaf atau mayoritas dikerjakan oleh mukallaf (Shan'ani, 1988: 109). Salah seorang ulama khalaf, Abdul Karim Zaidan mendefinisikan 'umūm al-balwā dengan ungkapan menyebarnya kondisi yang dihadapkan kepada manusia di mana manusia sulit menghindar darinya (Zaidan, 2001: 61).

Sedangkan 'Abdul Majid Salahin mendefinisikan 'umūm al-balwā dengan adanya kondisi yang menyeluruh terhadap mayoritas mukallaf pada waktu tertentu atau sering terjadi pada seseorang mukallaf dalam banyak waktu dan menyebabkan terjadinya kesulitan sehingga menghendaki adanya keringanan dalam pentaklifan syariat (Kawari, : 35).

Konsep 'umūm al-balwā dalam praktiknya sekarang ini bisa berpengaruh pada hal-hal kontemporer yang bermakna masa kini (Kemendiknas, 2008: 751). Tema maslahat dan mafsadah menjadi term yang menentukan hukum-hukum syari'ah sebagaimana dalam penerapan 'umüm al-balwā yang menegaskan bahwa nilai, makna, dan eksistensi kemaslahatan 
berada pada posisi di atas otoritas teks dalam penentuan hukum Islam (Thahir, 2015: 83).

Keadaan berat dan sulit (masyaqqah dan ḩaraj) mempunyai otoritas besar terjadinya transformasi hukum fikih yaitu ketika berada pada berbagai permasalahan yang memang susah dihindari. Suatu kondisi yang sulit dihindari atau 'umūm al-balwā masuk dalam tujuh kategori yang secara tidak langsung menjadi penyebab dispensasi atau keringanan syar'i sehingga bisa dipastikan bahwa kesulitan dan kepayahan yang dimaksudkan oleh syar'i tersebut selalu ada pada tujuh hal tersebut (Abbas, 2004: 89-101). Berbagai kondisi yang menunjukkan adanya 'umūm al-balwā berdampak pada perubahan hukum dan mempengaruhi hukum fikih yang pada akhirnya ditolerir dan dimaafkan (al Zuhailiy, 1997: 229-230).

Berbagai definisi yang dibahas sebelumnya menunjukkan bahwa penerapan 'umum al-balwa tidak jauh berbeda dengan penerapan sebuah teks syari'ah yang semestinya tidak dilakukan dengan cara parsial apalagi sampai memarginalkan konsep-konsep lainnya. Penerapannya harus komprehensif supaya menghasilkan produk hukum yang tidak sempit dan relevan dengan dinamika kehidupan masyarakat (Alimuddin, 2014: 13-14).

\section{Substansi 'umūm al balwā}

Paradigma literalistik umūm al-balwā dalam penalaran fikih dan usul fikih yang klasik menunjukkan bahwa perilaku-perilaku sosial masyarakat tidak luput dari perhatian hukum Islam (Idrus, 2013: 16). Hal tersebut dipersepsikan bahwa aspek penalaran mempunyai kecenderungan dinamis dan relevan dengan sifatnya yang profan dan tetap bernuansa transendental. Dalam ungkapan lain, berdimensi insani dan tetap terintegrasi dengan dimensi ilahi. Hal tersebut menunjukkan bahwa dinamika kehidupan sosial masyarakat harus tetap menyesuaikan dengan nilai-nilai hukum Islam karena karakteristik hukum Islam dikenal dengan cakupan kesempurnaan, universal, ta'abbudi-ta'aqquli, elastis-dinamis, dan sistematis (Khallaf, 1987: 53).

Konsep 'umūm al-balwā tidak lepas dari adanya perubahan sosial, budaya, sains, dan teknologi yang tidak mungkin terhindarkan. Konsep 'umūm al-balwā dalam dinamika kehidupan sosial tidak mungkin termarginalkan dan tidak terpisahkan dari maqāsid asy-syari'ah yang memudahkan bagi mukallaf dengan orientasi maslahat umat. Konsep 'umūm al-balwā dalam bentuk mu'amalah didalamnya terkandung sifat ta'aqquli yang bersifat duniawi dengan makna 
dapat dipahami oleh nalar rasional sehingga manusia dapat melakukannya dengan bantuan nalar dan pemikiran manusia. Illat dari mu'amalah yang bersifat ta'aqquli dirasionalkan dengan melihat maslahat atau mudarat di dalamnya (Syarifuddin, 2009: 53).

Konsep umu:̧m al-balwā mempertegas bahwa fikih tidak lahir dari ruang hampa, melainkan terlahir di tengah dinamika pergulatan kehidupan sebagai jawaban atas problematika aktual yang selalu berkembang dan berubah seiring dengan perkembangan dan perubahan masyarakat itu sendiri (Sholehuddin, 2013: 171). Maslahat yang ada dalam umüm al-balwā menjadi poros yang selalu berkembang seiring dengan perkembangan zaman yang terus bergerak sehingga konsep 'umūm al-balwā senantiasa akan menjadi kebutuhan dalam mengantisipasi kondisi serta peristiwa yang berkemungkinan mengancam karena berada dalam posisi dilematis atau tujuan syari'at kontradiktif dengan realitas yang ada.

Berkemungkinan menjadi media dengan realitas kesulitan yang ada, mendatangkan kemudahan dalam bentuk dispensasi hukum yang biasa diistilahkan dengan rukhșah (keringanan) (Abbas, 2004: 77). Subtansi dari konsep 'umūm al-balwā berarti mendeskripsikan watak yang sebenarnya dari sesuatu, menunjukkan isi, pokok, dan inti dari 'umūm al-balwā sehingga problematika yang dialami dapat dirumuskan secara konkret, benar-benar ada, dapat dilihat, dan dapat dirasakan. Selanjutnya dengan problema yang dihadapi diberikan formula yang tepat dan akurat sehingga diberikan keringanan atau rukhsah sebagai kompensasi yang bertujuan memberikan kenyamanan dan kepuasan dalam suatu bidang untuk memperoleh keseimbangan dari kesulitan dalam bidang lain.

Hanya saja yang perlu diperhatikan dalam menerapkan'umūm al-balwā adalah batasanbatasannya yang jelas dan dapat diformulasikan secara konkret sehingga liberalisasi dan marginalisasi tipologi hukum Islam yang tekstual bisa diminimalisir sedini mungkin. Formulasi selanjutnya dengan upaya preventif dan menghindarkan beragam upaya pemutarbalikan fakta, aturan, dan penyimpangan. Biasanya dalih yang selalu muncul adalah Islam yaitu dengan memberikan kemudahan bukan malah didistorsi sehingga yang terlihat di permukaan adalah tasa $>$ bul (memudah-mudahkan).

Problematika yang dihadapi masyarakat tidak lepas dari perkembangan zaman dan dikesankan terlalu digampangkan dengan dalih persoalan tersebut sangat susah dihindari karena sudah bersifat sistemik. Diperlukan prosedur penerapan 'umüm al-balwā yang sesuai 
dengan batasan-batasannya yang selaras dengan beragam contoh yang pernah diterapkan pada masa Rasulullah saw. dan sahabat yang kemudian berbagai amalan tersebut menunjukkan kategori 'umūm al-balwā dan kepastian hukum mengenai masalah yang dihadapi pada masa sekarang.

Fatwa-fatwa yang dikeluarkan semestinya mencerminkan tradisi analitis dan kritis sebagai upaya merespon hukum persoalan baru tidak lagi terkesan tasāhul (memudah-mudahkan) karena hanya didasarkan kepentingan individu dan hawa nafsu padahal maslahat harus selalu berorientasi kemaslahatan umat bukan kemaslahatan ego manusia yang dampaknya mengarah hal-hal yang destruktif. Elaborasi 'umūm al-balwā dari aspek linguistik dan terminologinya dari ulama salaf dan khalaf harus selalu bertumpu pada kasus-kasus yang pernah terjadi dan terekam dalam literatur fikih klasik. Kasus-kasus dalam fikih klasik tersebut bukan hanya menunjukkan tekstual dan lahiriahnya saja tapi juga menunjukkan maqāsid teksnya.

Kata al-umüm secara etimologis yang berarti al-tūl (sesuatu yang panjang), al-kasrah (sesuatu yang banyak), al-'uluwwu (sesuatu yang tinggi), al-syumulu (sesuatu yang mencakup) (Manzur: 321) dan kata al-balwiā yang berarti ujian, cobaan atau bencana (Manzur: 90). Lafal al-balwā sejalan dengan beberapa ayat yang diungkapkan dalam Alquran, seperti Q.S. Muhammad/47: 4, QS al-Anbiya/21: 35, QS 'Ali Imran/3: 186, yang substansinya menunjukkan adanya beban yang seharusnya dipikul dan dilaksanakan namun terasa sulit dihindarkan, baik karena seringnya terjadi atau hal tersebut sudah berlaku umum di masyarakat. Meratanya sebuah peristiwa atau pentaklifan yang dibebankan terhadap orang yang menjalani syari'at sementara realitasnya sangat susah menghindari (Dausiri, 2000: 61).

Dalil-dalil yang terdapat dalam al-Quran sarat dengan dimensi insani dan konsep 'umūm al-balwa a adalah penyebab terjadinya dispensasi hukum yang bersumber dari nas secara langsung atau prinsip-prinsip umum syari'ah. Salah satu dari ayat al-Quran QS al-Nisa/4: 28 menyatakan bahwa Allah senantiasa memberikan keringanan kepadamu karena manusia diciptakan bersifat lemah.

Dalil tersebut secara komprehensif menginginkan kemudahan dan tidak ingin memberatkannya hamba-Nya dengan pertimbangan keterbatasan manusia dalam kondisi tertentu. Suatu kondisi yang sulit dihindari bagi mukallaf dan tertuntut untuk melaksanakannya dalam kondisi normal tentu bertentangan dengan semangat syari'ah. Konsensus ulama dalam 
membebankan taklif tidak untuk mempersulit dan adanya kesulitan bukan bagian dari tujuan syari'at. Perihal kesulitan yang terjadi dalam tasyri' (pelaksanaan syari'ah) adalah kontradiksi dalam syari'ah itu sendiri (Syatibi, 2003: 212).

Praktik konsep 'umūm al-balwā lebih bernuansa sosiologis sehingga pengembangan hukum Islam diarahkan untuk merespon kebutuhan masyarakat yang aktual, sebagai sarana perubahan atau rekayasa sosial. Islam dapat memberikan solusi bagi masyarakat modern sebagaimana ia dapat memberi solusi bagi persoalan masyarakat tradisional seperti halnya dengan musibah umum yang terjadi dalam masyarakat dan sulit dielakkan (Nasution, 1985: 13-14). Keadaan berat dan sulit (mashaqqah dan haraj) didalamnya berdampak dengan pemberlakuan otoritas besar terhadap kemungkinan terjadinya transformasi hukum fikih sebagaimana yang tergambarkan dalam kondisi-kondisi yang umum terjadi yang selanjutnya mengantarkan kepada perubahan hukum-hukum najis menjadi ma'fu (ditolerir) (Nujaim: 83).

Wacana 'umūm al-balwā yang kasusnya tergambarkan dalam riwayat Abu Qatadah tentang kucing yang minum dalam bejana dengan berbagai kasus 'umūm al-balwā pada masa sekarang diibaratkan sebagai pertautan al-turäth dan al-tajdid. Persepsi tersebut menekankan bahwa pemikiran fikih akan terus mengalami perubahan seiring dengan perubahan sosial (Sholehuddin, 2013: 173). Menerima riwayat Abu Qatadah bagian dari al-turath sebagai suatu kebenaran yang masih dapat digunakan sebagai solusi bagi problem-problem masyarakat masa kini yang perlu dikontekstualisasikan dengan mengacu kepada kemaslahatan masyarakat, utamanya yang masuk dalam kategori 'umūm al-balwā (Sholehuddin, 2013: 181).

Konsep 'umūm al-balwā (musibah umum) yang terjadi dalam masyarakat bisa dianalisis berdasarkan beberapa fitur pendekatan sistem. Keenam fitur sistem yang ditawarkan Jasser Auda adalah kognisi, keutuhan, keterbukaan, interrelasi hierarki, multidimensional, dan berorientasi tujuan (Auda, 2008: 45-46).

\section{Pengaruh 'umūm al-balwā dalam dinamika kehidupan manusia}

Hukum Islam tidak hanya dipahami sebagai kumpulan peraturan yang berasal dari corpus jurisprudence Islam yang terbentuk secara historis di zaman lampau karena jika itu terjadi maka hal tersebut menjebak kepada pandangan yang pesimis dan melihat hukum Islam sebagai peninggalan masa lalu yang telah berwujud fosil. Namun harus dipahami bahwa 
hukum Islam bukan sekedar kumpulan konkret dalam corpus fikih karena mencakup tiga lapisan norma seperti: (1) norma-norma dasar, (2) asas-asas umum, (3) peraturan-peraturan konkret (Mustofa, 2009: 5).

Sebagian besar peraturan hukum konkret merupakan hasil ijtihad zaman tersebut dalam rangka memenuhi kebutuhan hukum saat itu. Bila zaman berlalu dan muncul berbagai variabel baru yang tidak ada saat dilakukannya ijtihad terhadap peraturan tersebut maka peraturan itu segera kehilangan relevansi. Asas hukum Islam menegaskan bahwa perubahan hukum disebabkan adanya perubahan berdimensi waktu dan berdimensi ruang. Perubahan peraturan hukum harus memenuhi tiga syarat, yaitu (1) ada tuntutan untuk melakukan perubahan, (2) peraturan tersebut tidak menyangkut substansi ibadah, dan (3) perubahan baru tersebut tertampung oleh nilai dan asas syariah lainnya (Mustofa, 2009: 5).

Perubahan-perubahan masyarakat tidak bisa dihindarkan karena selalu menampilkan perkembangan baru yang menuntut intervensi hukum Islam dalam memainkan peran penting dalam perkembangan kehidupan masyarakat. Hukum tidak hanya dipandang dari satu sisi belaka tetapi hukum dipandang juga secara sosiologis yang mampu mengakomodir perubahan-perubahan yang terjadi (Anwar, 2013: 99-100). Persoalan-persoalan yang muncul ke permukaan tanpa mampu diantisipasi dan dicarikan solusinya oleh umat Islam secara baik dan apalagi tuntas tentu saja menjadikan hukum Islam seolah tidak siap menghadapi tantangan zaman bahkan bisa saja dianggap tidak relevan untuk diterapkan di dunia modern.

Sebagian kalangan menyatakan bahwa pemikiran hukum Islam hingga saat ini masih didominasi oleh pemikiran yang bersifat ideologis karena cenderung melanggengkan status quo. Akibatnya pemikiran hukum Islam mengalami kesulitan ketika harus berhadapan dengan realitas kekinian (Gibb, 1996: 109-112). Harus diakui bahwa mulanya hukum Islam tumbuh secara fleksibel dan dinamis mengikuti tuntutan zaman. Konsistensi dalam mempertahankan prinsip-prinsip dasar yang tidak berubah dari risalah kerasulan Muhammad.

Dinamisasi dan soliditas menjadikan karakteristik utama hukum Islam di sepanjang zaman. Aspek dinamisasi tersebut menjadikan hukum Islam tidak statis dan fleksibiltas selalu mengikuti perubahan dan perkembangan zaman. Soliditas hukum Islam tidak sepenuhnya tergerus dengan tuntutan zaman sehingga tidak kehilangan jati dirinya (Fanani, 1999: 107). Eksistensi konsep 'umūm al-balwā menggiring mukallaf berimprovisasi atau menyediakan 
sikap kejiwaan yang luwes, lentur dan fleksibel berdasarkan bahan yang seadanya sehingga terasa nyaman dalam bersikap dan menjalankan taklif.

Penerapan 'umum al-balwa memungkinkan selama kriteria-kriterianya terpenuhi dan dapat diketahui melalui sebab-sebab dan syarat-syarat yang disimpulkan melalui contoh kasus dan peristiwa yang terjadi masa Rasulullah saw. dan sahabat. Penerapannya dalam kasus-kasus yang aktual diperlukan pendekatan seperti pendekatan berbasis al-ädah wa al-urf, pendekatan maslahat, pendekatan al-zara'i sehingga mempunyai hubungan timbal balik atau sebab akibat (korelasi) dengan dinamika perkembangan masyarakat sepanjang zaman (Alimuddin, 2014).

Multi pendekatan yang dipergunakan dalam menerapkan konsep 'umum al-balwa dapat dipahami dan berpengaruh pada persepsi yang mengukuhkan bahwa sesungguhnya hukum Islam dibangun beriringan dengan wahyu Allah dan kekuatan penalaran manusia sehingga produknya sesuai dengan tingkat kemajuan masyarakat dan mampu mengatasi permasalahan yang dihadapi tetapi dalam bingkai semangat, jiwa dan tujuan syariat Islam (Ash-Shiddieqy, 1978: 214).

Kekuatan dari penalaran tersebut merupakan proses berpikir dalam menarik kesimpulan berupa pengetahuan tentang 'umu>m al-balwa $>$ karena memang dikaitkan dengan berpikir dan bukan dengan penasaran yang mempunyai karakteristik tertentu dalam menemukan kebenaran dan bukannya pembenaran pernyataan dan tindakan manusia yang jelas kontradiktif dengan ketentuan nas (Salam, 2003: 139).

Dispensasi hukum yang diidentifikasi dalam 'umūm al-balwāa dengan mengetahui sebab terjadinya dalam berbagai hal, seperti adanya kesukaran yang susah untuk dihindari, peristiwa atau perbuatan yang sering berulang, meratanya peristiwa tersebut dalam masyarakat, adanya faktor sedikitnya kadar suatu perbuatan peristiwa pada kondisi umum yang dialami mukallaf secara psikologis, kondisi lanjut usia atau penyakit tertentu yang susah untuk disembuhkan, dan adanya kondisi darurat. Berbagai sebab yang disebutkan sebagai akibat timbulnya dispensasi hukum dipertautkan pada pola pikir yang mengarah pada kebiasaan, psikologis individu dan insiden yang tidak terduga.

Perubahan zaman menjadi indikator adanya perubahan hukum dalam 'umūm al-balwa sehingga hukum yang dilandaskan pada tradisi berubah seiring dengan perubahan zaman dan bisa jadi perubahan tersebut terjadi karena berubahnya ideologi pemikiran manusia (al 
Bahsin, 2011: 459). Ulama khalaf memfatwakan bolehnya imam masjid, guru mengaji dan muballig sehingga dianggap bertentangan dengan fatwa ulama salaf karena adanya perubahan zaman dengan alasan jika fatwa ulama salaf yang diterapkan akan berimplikasi pada syiar Islam dan pengajaran Alquran yang lambat laun akan hilang (Zuhaily, 1986: 835).

Konsep 'umūm al-balwa dalam berbagai kasus lainnya pernah diterapkan dalam fatwa Imam Abu Hanifah pada awal kedatangan Islam di Persia dengan bolehnya melaksanakan salat dengan menggunakan bahasa Persia karena tidak dapat mengucapkannya dengan bahasa Arab. Namun kesulitan tersebut harus dihilangkan dengan usaha maksimal sehingga saat mereka dapat mengucapkannya dengan bahasa Arab maka Imam Abu Hanifah merubah fatwanya dan mengharuskan salat dengan menggunakan bahasa Arab (Dausiri, 2000: 409). Kondisi tersebut menunjukkan bahwa hukum yang dihasilkan dari penerapan 'umūm al-balwa dapat berubah seiring dengan perubahan zaman dan keadaannya.

Pertimbangan menganalisa tingkatan maslahat dalam menerapkan 'umūm al-balwāa ditinjau secara hirarkis dalam bentuk primer, sekunder, dan pelengkap karena inti dari sebuah maslahat adalah rahmat yang berwujud manfaat dan kebahagiaan umat manusia (Buti, 2010: 87). Penerapan 'umūm al-balwā dengan berlandaskan penalaran berbasis maqasid menjadikan tujuan atau illat penetapan hukum sebagai tujuan kemaslahatan umat manusia.

Keberadaan 'umūm al-balwā dengan basis literalistiknya harus mengacu pemahaman makna teks ayat atau hadis. Selanjutnya diiringi dengan paradigma maqăsid yaitu pengembangan paradigma usul fikih klasik dengan tujuan terwujudnya dispensasi hukum yang dipastikan sejalan dengan spirit hukum Islam. Aspek kemaslahatan dengan diberikannya dispensasi hukum dalam 'umūm al-balwā tidak hanya terpaku pada literalisme teks tetapi juga mencerminkan adanya perubahan dari rasionalisme deduktif menjadi rasionalisme induktif (Syatibi, 2003: 29-34).

Konsep 'umūm al-balwā teridentifikasi sebagai wujud sosialisasi Islam yang progresif dan berjalan terus menciptakan keseimbangan walaupun ada kendala atau mashaqqah (kesulitan) didalamnya (Mawardi, 2010: 207). Pemberlakuan dispensasi dalam 'umūm al-balwā di tengah masyarakat sangat berpengaruh karena dinamisasi dalam kehidupan masyarakat. Kehadiran fikih mengiringi pasang surut perkembangan hukum Islam utamanya dalam berbagai kejadian yang dikategorikan 'umūm al-balwā bahkan mewarnai dan memberi corak bagi perkembangan 
hukum Islam dari masa ke masa (Idrus, 2011: 34).

Bahkan posisi urfatau adat kebiasaan dalam profil 'umūm al-balwā menjadi penting dengan kenyataan bahwa urfitulah yang menjadi the living law (hukum yang hidup) dalam masyarakat. Kebiasaan sebagai unsur dalam 'umūm al-balwā tetap berjalan baik dengan upaya diakomodasi sebagai bagian dari hukum. Dalil-dalil hukum Islam dalam konsep 'umūm al-balwā tidak dibiarkan menjauh dari kenyataan sosial apalagi sampai mengebiri hukum Islam itu sendiri. Formula teks dan konteksnya tetap bisa dipertemukan, dalil hukum dan illat hukumnya dapat dianalisis dengan kebiasaan yang tercermin dalam 'umūm al-balwā sehingga dapat diakomodasi dan diberikan dispensasi hukum.

\section{Penutup}

Berdasarkan pemaparan tersebut maka dapat dipahami bahwa konsep 'umūm al-balwā dalam kehidupan masyarakat digambarkan sebagai bentuk realitas hidup manusia yang didalamnya ditemukan kesulitan. Keberadaan musibah umum yang menimpa realitas kehidupan menuntut diberikannya dispensasi hukum sebagai bentuk mengakomodir terwujudnya maslahat yang berbasis tujuan dari eksistensi hukum Islam itu sendiri. Konsep 'umūm al-balwā telah tergambarkan pada perkara dalam riwayat Abu Qatadah ra. tentang kucing yang meminum dari bejana air sedangkan kucing adalah hewan yang suka makan bangkai dan tikus.

Kondisi tersebut memungkinkan terjadinya keumuman yang susah dihindari dan menjadi penyebab terjadinya pengecualian dari aturan hukum karena adanya pertimbangan khusus yaitu sulit menghindari diri karena keumumannya terjadi dalam masyarakat. Pemaknaan konsep 'umüm al-balwā dengan pemaknaan etimologis dan terminologis yang selanjutnya disertakan penunjukkan dalilnya dari Alquran dan sunnah Rasulullah saw. supaya bisa dijadikan acuan dan bahan untuk mempertautkan perkara yang pernah terjadi tentang 'umüm al-balwa dengan dalil yang sudah ada.

Perkara klasik dengan muatan 'umüm al-balwā didalamnya sebagai putusan (justifikasi) dan upaya menjembatani terhadap perkara-perkara yang bisa saja dialami manusia sekarang ini dalam berbagai bidang namun dengan pertimbangan khusus yaitu dengan ketentuannya susah untuk dihindari dan menghindarkan diri karena masuk dari bahagian kehidupan manusia. Konsep 'umūm al-balwā dengan riwayat Abu Qatadah ra. sebagai perkara klasik dengan 
penunjukan dalilnya tersebut dijadikan sebagai bahan acuan untuk dihubungkan dengan perkara yang sifatnya up to date (tidak ketinggalan jaman) atau belum terjadi sebelumnya namun dengan tetap menyertakan pertimbangan khususnya yaitu keumumannya yang susah dihindari.

Pertimbangan itu yang selanjutnya diakomodir oleh ketetapan hukum Islam supaya diberikan dispensasi karena adanya kesamaan illat atau motif hukum sehingga bisa dipertautkan dengan perkara lainnya tidak mesti dalam hal ibadah, sebagaimana yang terjadi dalam riwayat Abu Qatadah namun juga bisa merambah ke bidang lainnya seperti perkaraperkara yang bersentuhan dengan teknologi medis, ibadah haji dengan menggunakan obat penunda haid bagi perempuan. Adanya unsur mashaqqah (kesulitan) sementara suatu perkara masuk dalam kategori kebutuhan manusia yang sangat signifikan menjadi kunci dan upaya merespon sehingga terealisasi raf'u al-haraj (terlepas bebannya).

\section{Daftar pustaka}

Abbas, Ahmad Sudirman. Qawa'id Fiqhiyyah dalam Perspektif Fiqh. Cet. I; Jakarta: Pedoman Ilmu Jaya \& Anglo Media Jakarta, 2004.

Abdain. "Produk Pemikiran Hukum Islam", Jurnal Kajian Hukum Islam al-Abkam,Volume 3, No. 1, Oktober 2013.

Ali, Zainuddin. Sosiologi Hukum. Cet. VII; Jakarta: Sinar Grafika, 2012.

Alimuddin, Harwis. "Metode Penerapan Umum al-Balwa dalam Fikih Kontemporer", Tesis Magister. Makassar: UIN Alauddin Makassar, 2014.

Anwar, Yesril. \& Adang. Pengantar Sosiologi Hukum. Jakarta: Grasindo, 2013.

Ash-Shiddieqy, T. M. Hasbi. Pengantar Ushul Fiqh. Jakarta: Bulan Bintang, 1978.

Auda, Jasser. Maqasid al-Shariah as Philosophy of Islamic Law,: A System Approach. USA, UK: The International of Islamic Thought, 2008.

Bahsin, Ya'qub bin Abdul Wahab al-. al Mufassal fi al-Qawa'id al-Fiqhiyyah. Riyad: Dar al-Tadmuriyyah, 2011.

Bustani, Karam al-. Al Munjid fi al-Lugah wa al-A'lam. Beirut: Dar al-Masyriq, 1992.

Buti, Muhammad Sa’id Ramadan al-. Dawabit al-Maslahah fi al-Syari'ah al-Islamiyyah. al-Qahirah: Dar al-Fikr, 2010.

Djalil, H. A. Basiq. Ilmu Ushul Fiqih 1-2. Jakarta: Kencana Prenada Media, 2010.

ad-Dausiri, Abu Muslim. Umum al-Balwa Dirasah Nazariyyah Tatbiqiyyah. Riyad: Maktabah al-Rusyd, 2000. 
Fanani, Muhyar. Fiqih Konstruksi Hukum Islam Madani di Dunia Modern. Yogyakarta: LkiS Printing Cemerlang, 2009.

Garisyah, Ali. Metode Pemikiran Islam. Jakarta: Gema Insani Press, 1989.

H.A.R Gibb. Aliran-Aliran Modern dalam Islam. Jakarta: Rajawali Press, 1996.

Ibrahim, Ahmad Syauqi. al-Ma'arif al Tibbiyyah fi Daw'i al-Qur'an al-Karim. al-Qahirah: Dar al-Fikr al-Arabiy, 2002.

Idrus, Achmad Musyahid. Melacak Aspek-Aspek Sosiologis dalam Penetapan Hukum Islam. Makassar: Alauddin University Press, 2012.

Idrus, Achmad Musyahid. Perkembangan Penalaran Filosofis dalam Hukum Islam. Makassar: Alauddin University Press, 2013.

Ismatullah, Dedi. Sejarah Sosial Hukum Islam. Bandung: Pustaka Setia, 2011.

Ismail, Sya'ban Muhammad. Ushul Fiqh Tarikbubu wa Rijalubu. Riyadh: Dar al-Tab’i wa al Nasyr, 1981.

Kamma, Hamzah. Usul Figh Metode Penggalian Hukum Islam. Palopo: Lembaga Penerbitan STAIN Palopo, 2012.

Kawari, Mus'ab Mahmud Ahmad. Umum al-Balwa wa A'sarubu ala al-Khabar al-Wahid. Gazzah: al-Jami'ah al-Islamiyyah bi al-Gazzah, 2010.

Khallaf, Abd. Wahab. Khulasah Tarikh Tasyri' Islami. Misr: Dar al-Kutub al-Arabiyyah, 1987. al-Khadari, Muhammad. Usul al-Fighi. al-Qahirah: al-Maktabah al-Tijariyah al-Kubra, 1969. Majma' al Malik Fahd. Al Qur'an dan Terjemabnya (Madinah: Yayasan Malik Fahd Percetakan Mushaf.

Mahmasani, Subhi. Falsafah al-Tasyri fi al-Islam. Beirut: Dar al-Kasysyaf, 1952.

al Malibari, Zainuddin bin Abdul Aziz Fathu al-Muin bi Syarhi Qurrati al-Ain. Surabaya: al-Hidayah, t.th.

Mawardi, Ahmad Imam. Fiqh Minoritas: Fiqh al-Aqalliyyat dan Evolusi Maqasid al-Syari'ah dari Konsep ke Pendekatan. Cet. I; Yogyakarta: LkiS Yogyakarta, 2010.

Manzur, Ibnu. Lisan al-Arab Jilid XV. al-Qahirah: Dar al-Ma'arif, t.th.

Minhajuddin-Misbahuddin, Usul Fikih II. Makassar: Alauddin Press, 2010.

Muhammad Ashi dan Rapung Samuddin, Hukum Internasional dan Hukum Islam tentang Sengketa dan Perdamaian.Jakarta: Gramedia Pustaka Utama, 2013.

Mustofa \& Abdul Wahid. Hukum Islam Kontemporer. Cet. I; Jakarta: Sinar Grafika, 2009.

Musyahid, Ahmad. Validasi Studi Orientalisme terhadap Sejarah Sosial Hukum Islam. Cet. I; Makassar: Alauddin University Press, 2011.

Moh. Sholehuddin. Dinamika Nalar Fikih "Tradisi” NU: Dari Periode Penegasan Identitas Menuju 
Periode Aktualisasi, Volume 16, Nomor 1, Mei 2013 al-Adalah Jurnal Kajian Keislaman dan Kemasyarakatan STAIN Jember Press.

al-Nadwi, Ali Ahmad. al-Qawa'id al-Fiqhiyyah. Damaskus: Dar al-Qalam, 1991.

Nasution, Harun. Dasar Pemikiran Pembaharuan dalam Islam, dalam M. Yunan Yusuf, et. al. (ed.), Cita dan Citra Muhammadiyah. Jakarta: Pustaka Panjimas, 1985.

Nujaim, Zain al-'Abidin bin Ibrahim Ibnu. al-Asybah wa al-Naza'ir. Beirut: Dar al-Ma'rifah, t.th.

al-Qaradawi, Yusuf. Madkhal li al-Dirasah al-Syari'ah al-Islamiyah. al-Qahirah: Dar al-Garib li al-Taba'ah, 1981.

al-Qaradhawi, Yusuf. Syari'atu al-Islam Saliah li al-Tatbiq fi Kulli Zaman wa Makanin (al-Qahirah: Maktabah al-Wahbah, 1997.

Salam, Burhanuddin. Logika Materil Filsafat Ilmu Pengetahuan. Jakarta: PT. Rineka Cipta, 2003. al-San'ani, Muhammad Ibnu Isma'il al-Amir. Ijabatu al-Sail Syarbu Bagiyyati al-Amiled. Husain Ibnu Muhammad al-Siyagi. Bairut: Muassasah al-Risalah, 1988.

Syaltut, Mahmud. al-Islam; Aqidah wa Syariah. Mesir: Dar al-Qalam, 1966.

Sultan, Lomba. Dinamika Perkembangan Hukum Islam dari Masa ke Masa. Makassar: Alauddin University Press, 2014.

al-Syathibi, Abu Ishaq. al-Muwafaqatfi Ushul al-Syari'ah, Juz I. Bairut: al-Maktabah al-Asriyyah, $2003 \mathrm{M} / 1423 \mathrm{H}$.

Syarifuddin, Amir. Usul Fiqh Jilid I. Jakarta: Kencana Prenada Media Group, 2009.

al-Tufi, Najmuddin Abi al-Rabi' Sulaiman Ibnu 'Abdu al-Qawiy Ibnu 'Abdu al-Karim Ibnu Sa'id. Syarhu Mukhtasar al-Raudah ed. 'Abd Allah Ibnu 'Abdul Muhsin al-Turki, Jiid II. al-Mamlakah al-'Arabiyah al-Saudiyyah; Wizarah al-Syuun al-Islamiyyah, 1998.

Tim Penyusun Kamus Pusat Bahasa, Kamus Bahasa Indonesia. Jakarta: Pusat Bahasa, 2008.

Thahir, Halil Ijtihad Maqasidi Rekonstruksi Hukum Islam Berbasis Interkoneksitas Maslahah. Yogyakarta: LkiS Printing Cemerlang, 2015.

al-Zarqa',Ahmad bin Muhammad. Syarbu al-Qawa'id al-Fiqhiyyah. Dimasyq: Dar al-Qalam, 2012.

Zaidan, 'Abd al-Karim. al-Wajiz fi Syarbi al-Qawa'id al-Fiqhiyyah fi al-Syari'ah al-Islamiyyah. Bairut: Muassasah al-Risalah, 2001.

al-Zuhaily, Wahbah. al-Wajizfi Usul al-Fiqh. Beirut: Dar al-Fikr al-Mu'asir, 1997.

al-Zuhaili, Wahbah. Usul al-Figh al-Islami, Jilid II. Dimasyq: Dar al-Fikr, 1986. 